\begin{tabular}{|c|c|}
\hline \multicolumn{2}{|c|}{ PublisherInfo } \\
\hline PublisherName & Palgrave Macmillan UK \\
\hline PublisherLocation & London \\
\hline PublisherImprintName & Palgrave Macmillan \\
\hline
\end{tabular}

\title{
The launch of the Index of Services as a National Statistic
}

\begin{tabular}{||l|l|l||}
\hline \multicolumn{2}{|c|}{ ArticleInfo } \\
\hline \hline ArticleDOI & $:$ & $10.1057 /$ palgrave.elmr.1410043 \\
\hline \hline ArticleCategory & $:$ & Feature \\
\hline \hline ArticleFirstPage & $:$ & 39 \\
\hline \hline ArticleLastPage & $:$ & 46 \\
\hline \hline & & RegistrationDate $:$ 2007-3-16 \\
ArticleHistory & $:$ & OnlineDate $\quad$ 2007-3-16 \\
\hline \hline ArticleCopyright & $:$ & Crown copyright2007 \\
\hline \hline
\end{tabular}


Steve Drew, ${ }^{\text {Affl }}$

Darren Morgan, ${ }^{\text {Aff1 }}$

\section{Describes the significant improvements that the IoS development programme has brought to measuring service sector output.}

The service sector, since 1970, has increased from 53 per cent of the economy to 74 per cent today. It is nowby far the largest and fastest changing sector of the UK economy. This article describes the significant improvementsthat the Index of Services (IoS) development programme has brought to the measurement of the output ofthe service sector, as well as the output measure of gross domestic product. The article also plots the journey of the IoSfrom its launch in December 2000 as an experimental statistic to its expected reclassification on 29 March 2007 as aNational Statistic.

Misc

The Full Text of this article can be found on the National Statistics website (http://www.statistics.gov.uk/elmr/03_07/downloads/ELMR03_07Drew_Morgan.pdf). 